\title{
Measures of Aggression in Young Korean Children: A Review of 10 Years of Empirical Research
}

\author{
Hana Song , Jooreun Kim, Hanna Yoo \\ Department of Child Psychology \& Education, Sungkyunkwan University, South Korea
}

Copyright (C) 2015 by authors, all rights reserved. Authors agree that this article remain permanently open access under the terms of the Creative Commons Attribution License 4.0 International License

\begin{abstract}
The present study reviewed types of Korean versions of aggression measures for preschool children, which have been used in recent studies of Korea, and then examined the evidence of the reliability and validity of the measures. We also examined gender differences using meta-analysis. Forty six articles, which were published from 2005 through 2014, were selected from scientific databases. Results showed that the PSBS was most frequently used, followed by the PBQ, the CBCL and the SCBE in Korea. Cronbach's alpha ranged between .70 and .97 across measures except one, indicating acceptable levels of internal consistency. The result of the meta-analysis indicated that boys displayed significantly higher aggression. This was consistent in findings of previous studies, stating that boys showed more overt aggression than did girls. However, gender difference in relational aggression was not significant. The results of this study provide information how reliable and valid measures are to researchers aiming to conduct a comparative cultural study involving Korea. In the future, relational aggression will need to be assessed from multiple informants such as peers, teachers, parents, and observers.
\end{abstract}

Keywords Aggressive Behaviors, Preschool Children, Reliability and Validity, Meta-analysis, Gender Difference

\section{Introduction}

Aggressive behavior of preschool children has been a popular research topic in many countries [1]. Prior research has shown that aggressive preschoolers, compared to nonaggressive peers, were more likely to experience difficulty in school adjustment and interpersonal interactions [2]. In addition, aggressive preschoolers seem to show maladaptive behaviors and psychopathological problems later in life, such as oppositional defiant disorder and conduct disorder, more frequently than did nonaggressive peers $[3,4]$. Thus, it is of greater importance in assessing children's aggressive behaviors in early years.

Previous studies [5, 6] have identified three forms of aggressive behaviors: physical, verbal, and relational aggression. Physical aggression includes hitting, kicking, biting, and so on, and cursing and name-calling are regarded as verbal aggression. These two forms of aggression are overtly shown in social situations $[7,8]$. On the other hand, relational aggression concerns covert behaviors such as social exclusion and spreading rumors intended to harm others' social status and reputation. It has been known that relational aggression is more common in adolescents [9], but a simple form of social exclusion (i.e., rejecting a child repeatedly) can be also observed in preschool play settings

Aggressive behaviors of Korean preschoolers have been commonly evaluated by reports of parents, teachers, and peers in family and school contexts. Due to lack of language fluency, interviews are rarely administered to infants and preschoolers. Instead, observation or behavior rating methods have been used more frequently in examining overt aggression [10]. On the other hand, teachers' reports or peer nominations can be a better way to identify victims or bullies of relational aggression, given the fact that relational manipulation occurs in a less visible way [11].

However, unfortunately, few scales that measure both overt and relational aggression in the preschool period have been standardized into Korean language. Numerous studies on aggressive behaviors of Korean preschoolers have used translated versions of Western scales, yet evidence of reliability and validity of these translations has not been fully examined.

Culturally inappropriate measures lead to biased interpretation of research findings [12]. When administering a measure to participants who speak a different language, items and subscales should be translated to deliver accurate meaning to the participants [13]. Without conducting a back translation procedure, it is hard to determine whether psychometric characteristics of Korean translations are comparable with those represented in the original versions. Researchers in Korea recognize the necessity of contemplating the selection of measurement approaches, but it is rarely mentioned whether researchers translated Korean translations back into English, checking the cultural equivalence between the two language versions. In particular, 
it is necessary to check validity and reliability of Korean translations of aggression measures for conducting cross-cultural comparison with other countries.

Three measures seem to have been most commonly used in Korea. The Child Behavior Checklist (CBCL) is a rating scale to evaluate externalizing and internalizing dimensions of behavior problems and is used worldwide [14]. CBCL/4-18 [15] and CBCL/1 $1 / 2-5$ and C-TRF [16] are used with preschool-aged children. The Korean-CBCL, standardized by Oh, Lee, Hong, Ha [17], is a translated form of $\mathrm{CBCL} / 4-18$. In the form, aggression is one of the subscales of externalizing behavior problems that contains items describing physical attack, talking out of turn, and so on. Parents, caregivers, and teachers (or other relevant observers) rate each item 0,1 and 2, and ratings from multiple informants are often recommended [18].

The Preschoolers Behavior Questionnaire (PBQ) is also commonly used in Korea as a screening tool for behavioral and emotional problems of 3- to 6-year-olds $[19,20,21]$. Teachers rate 36 items in Hostile-Aggressive, AnxiousFearful, and Hyperactive-Distractible dimensions from 0 to 2 , and identify children into a normal or deviant group. Items in the Hostile-Aggressive dimension are related to physical and verbal aggression such as kicking, hitting, fighting, and blaming others.

Of the measures for aggressive behaviors, Preschool Social Behavior Scale (PSBS) is teacher or peer rating scale that assess relational aggression as well overt aggression [22]. As mentioned earlier, although peer nomination is an effective way to evaluate indirect social aggression [23], the teacher rating questionnaire with a five-point Likert-type scale is more frequently used in Korea. There may be measures to evaluate preschoolers' aggression other than the CBCL, the PBQ, and the PSBS, but no systematic analysis has been conducted. Therefore, the present study investigated what kinds of measures of aggressive behavior have been used in Korea, as well as their evidence of reliability and validity.

In particular, it is noted that aggressive behaviors vary with child gender. It has been known that physical aggression is more common in boys, while relational aggression is more likely related to girls [3, 24]. The high prevalence of relational aggression in girls is especially salient during adolescence, in which peer conformity and popularity become critical components for social competence and school adaptation $[25,26]$. However, Smith, Calkins, Keane [27] reported that even children under the age of 3 showed relational aggression. Thus, it is surprising that previous meta-analytic review concluded that gender difference was marginal in relational aggression [28, 29]. Types of aggression measures may affect this finding because, for example, behavioral rating by teachers could be different from that by parents or by peers. For this reason, it would be necessary to examine gender differences in overt and relational aggression according to each type of measure used in Korean studies.

In summary, the present study reviewed types of Korean versions of aggression measures for preschool children, which have been used in recent articles of Korea, and then tried to find evidence of the reliability of the Korean measures. Then, we conducted meta-analysis to examine whether extent of gender differences depends on each type of measures.

\section{Method}

\section{Retrieval of studies}

In this study, 46 research articles in which aggressive behaviors of 3- to 6-year-old (western age) children were measured were analyzed. These articles, published in South Korea from 2005 to 2014, were selected from a representative scientific databases: Korean studies Information Service System (KISS), Research Information Sharing Service (RISS), DataBase Periodical Information Academic (DBpia) and Kyobo Scholar. The keywords, "aggression" (including "aggressive behavior"), "behavior problems", "preschooler", and "kindergartener" were used in the first search. Then, articles that did not specify aggressive subscales from comprehensive behavior problems were excluded.

\section{Exclusion of articles}

Only research articles in academic journals were considered, with the exception of theses, books, reports, and essays, among 1005 publications resulting from the search in the first stage. Literature review, qualitative research, case studies, intervention studies, and studies using the measure with an uncertain source or a combination of several measures were also excluded. After the exclusion of the articles whose quality was not properly supported, measures of aggressive behaviors in 46 articles were finally analyzed in this study.

\section{Literature review and meta-analysis of measures of aggressive behaviors}

Analyses were made to see what measures were used to assess aggressive behaviors in preschool children and how reliability and validity of the measures were reported in each of the articles. In addition, an attempt was made to identify gender differences by types of aggression. First, evidence of gender difference reported in the 46 articles was reviewed, and then, meta-analysis was performed on the 18 out of 46 articles that report means and standard deviations by gender. Several articles used a scale with fewer items than in the original scale. To control the effect of the difference of the number of items, means were recalculated by division with the suggested number of items and adjusted to reflect the original number of items.

Effect sizes (ES) were estimated by comparing two gender groups on overt and relational aggression. If a $95 \%$ confidence interval (CI) include zero, it means the gender difference is not statistically significant. According to the criteria suggested by Cohen [30], ES was considered small 
when it was less than .2, medium-sized when it was around .5, and large when it was at least .8. U3, the measure of nonoverlap, was also calculated. Cochran's Q test was performed to indicate statistical significance of heterogeneity of the effect sizes [31]. I2 index over 50\% also indicates that the percentage of variations across studies is caused not by change, but by heterogeneity [31]. Thus, the random effect model is required for meta-analysis. Meta-analysis in the present study was performed using the Comprehensive Meta-Analysis V3 program.

\section{Results}

Overall, six types of measures, which were translated into Korean, were used across the 46 articles (see in Table 1): the PSBS-T, the PBQ, the CBCL, the Social Competence and Behavior Evaluation (SCBE), Child Behavior Scale (CBS), and Social Behavior Rating Scale(SBRS). The PSBS was most frequently used (18 times, 39.1\%), followed by the PBQ (12 times, 26.1\%), the CBCL (7 times, 15.2\%), and the SCBE (5 times, 10.9\%). The CBS and the SBRS were used for three times and once respectively.

The CBCL was standardized in Korea, and the Korean-Child Behavior Checklist (K-CBCL) was used across the articles. All other measures were translated by various researchers. The CBCL was rated only by mothers, and the rest of the measures were rated by teachers. In one article using the PSBS, both mothers and teachers rated children's aggressive behaviors.

Then, the evidence of reliability for each measure was analyzed. In all of the 46 articles, Cronbach's alpha was reported as an index of reliability. Thirteen of the articles using the PSBS (72.2\%) and eight of those using the PBQ $(66.7 \%)$ reported alpha coefficient at or above .90 . In six of the articles using the CBCL (85.7\%) and in five of those using the SCBE, alpha coefficient at or above. 80 were reported. Alpha coefficient was set at .70 or lower in only one article using the PSBS. However, only two articles using the $P B Q$ and the SCBE verified the construct validity through factor analysis, and only one study examined the face validity of the PSBS. None of the 46 studies performed the back-translation process or checked the cultural equivalence.

Concerning gender differences in aggressive behaviors, as shown in Table 1, 18 out of 46 articles reported its significance. Six measures in table 1 contain various types of subscales of aggressive behaviors, but we identified each of them into two categories (overt and relational aggression) for further meta-analysis. In particular, overt aggression category included overt aggression subscale of the PSBS, Hostile-Aggressive subscale of the PBQ, and externalizing behavior problem dimension of the CBCL.

Table 1. Korean versions of the scales measuring preschoolers' aggressive behaviors

\begin{tabular}{|c|c|c|c|c|c|c|c|}
\hline \multirow{2}{*}{ Title of measure } & \multirow{2}{*}{$\begin{array}{c}\text { Authors of } \\
\text { measure }\end{array}$} & \multirow{2}{*}{$\begin{array}{l}\text { Authors of } \\
\text { Korean } \\
\text { articles }\end{array}$} & \multicolumn{3}{|c|}{ The number of participants (n) } & \multirow{2}{*}{$\begin{array}{l}\text { Reliability in Korean research } \\
\text { (Cronbach's alpha) }\end{array}$} & \multirow{2}{*}{$\begin{array}{l}\text { Gender } \\
\text { difference }\end{array}$} \\
\hline & & & By age & By gender & Total & & \\
\hline \multirow{18}{*}{$\begin{array}{c}\text { Preschool Social } \\
\text { Behavior Scale } \\
\text {-Teacher Form; (PSBS } \\
\text {-T) }\end{array}$} & \multirow{18}{*}{ [24] } & [41] & 3 years $(702)$ & $\begin{array}{l}\text { Boys (353) } \\
\text { Girls (349) }\end{array}$ & 702 & $\begin{array}{c}\text { Total aggression } \\
\text { (.86) by teacher report } \\
\text { (.88) by mother report }\end{array}$ & NA \\
\hline & & [42] & $\begin{array}{l}4 \text { years }(110) \\
5 \text { years }(210)\end{array}$ & $\begin{array}{l}\text { Boys (153) } \\
\text { Girls (167) }\end{array}$ & 320 & $\begin{array}{c}\text { Overt }(.94) \\
\text { Relational }(.93) \\
\end{array}$ & NA \\
\hline & & \multirow{2}{*}[43]{} & \multirow{2}{*}{5 years $(112)$} & \multirow{2}{*}{$\begin{array}{l}\text { Boys (56) } \\
\text { Girls (56) }\end{array}$} & \multirow{2}{*}{112} & Overt (.96) & Boys \\
\hline & & & & & & Relational (.94) & none \\
\hline & & [44] & $\begin{array}{l}4 \text { years }(30) \\
5 \text { years }(26)\end{array}$ & $\begin{array}{l}\text { Boys (32) } \\
\text { Girls (24) }\end{array}$ & 56 & $\begin{array}{c}\text { Overt }(.74) \\
\text { Relational }(.79)\end{array}$ & NA \\
\hline & & \multirow{2}{*}[45]{} & 3 years $(57)$ & \multirow{2}{*}{$\begin{array}{l}\text { Boys (156) } \\
\text { Girls (166) }\end{array}$} & \multirow{2}{*}{322} & Overt (.97) & Boys \\
\hline & & & $\begin{array}{l}4 \text { years }(156) \\
5 \text { years }(109)\end{array}$ & & & Relational (.96) & none \\
\hline & & [46] & $\begin{array}{l}3 \text { years }(90) \\
4 \text { years }(92) \\
5 \text { years }(80)\end{array}$ & $\begin{array}{l}\text { Boys (130) } \\
\text { Girls (132) }\end{array}$ & 262 & $\begin{array}{c}\text { Overt (.94) } \\
\text { Relational (.93) }\end{array}$ & NA \\
\hline & & \multirow[b]{2}{*}{ [47] } & \multirow{2}{*}{$\begin{array}{l}3 \text { years }(119) \\
4 \text { years }(58) \\
5 \text { years }(73)\end{array}$} & \multirow{2}{*}{$\begin{array}{l}\text { Boys (151) } \\
\text { Girls (99) }\end{array}$} & \multirow[b]{2}{*}{250} & Overt (.91) & none \\
\hline & & & & & & Relational (.93) & Boys \\
\hline & & \multirow{2}{*}[48]{} & \multirow{2}{*}{$\begin{array}{l}4 \text { years }(124) \\
5 \text { years }(231)\end{array}$} & \multirow{2}{*}{$\begin{array}{l}\text { Boys (174) } \\
\text { Girls (181) }\end{array}$} & \multirow{2}{*}{355} & Overt (.94) & Boys \\
\hline & & & & & & Relational (.93) & Boys \\
\hline & & [49] & 5 years $(100)$ & $\begin{array}{l}\text { Boys (51) } \\
\text { Girls (49) }\end{array}$ & 100 & Overt (.91) & Boys \\
\hline & & \multirow{2}{*}[50]{} & \multirow{2}{*}{$\begin{array}{l}3 \text { years }(50) \\
4 \text { years }(51) \\
5 \text { years }(72)\end{array}$} & \multirow{2}{*}{$\begin{array}{l}\text { Boys (87) } \\
\text { Girls (86) }\end{array}$} & \multirow{2}{*}{173} & Overt (.92) & Boys \\
\hline & & & & & & Relational (.93) & none \\
\hline & & \multirow{2}{*}[51]{} & \multirow{2}{*}{$\begin{array}{c}4 \text { years }(106) \\
5 \text { years }(99)\end{array}$} & \multirow{2}{*}{$\begin{array}{l}\text { Boys (117) } \\
\text { Girls (88) }\end{array}$} & \multirow{2}{*}{205} & Overt (.61) & Boys \\
\hline & & & & & & Relational (.61) & Boys \\
\hline & & {$[52]$} & 4 years $(200)$ & $\begin{array}{l}\text { Boys (111) } \\
\text { Girls (89) }\end{array}$ & 200 & $\begin{array}{c}\text { Overt }(.93) \\
\text { Relational }(.93)\end{array}$ & NA \\
\hline
\end{tabular}




\begin{tabular}{|c|c|c|c|c|c|c|c|c|}
\hline & \multirow{9}{*}{$\begin{array}{c}{[5,22,32} \\
33]\end{array}$} & {$[53]$} & $3-5$ years $(338)$ & $\begin{array}{l}\text { Boys (176) } \\
\text { Girls (162) }\end{array}$ & 338 & Total aggression (.85) & NA \\
\hline & & & {$[54]$} & 3 years $(356)$ & $\begin{array}{l}\text { Boys (190) } \\
\text { Girls (166) }\end{array}$ & 356 & $\begin{array}{c}\text { Overt }(.83) \\
\text { Relational }(.92)\end{array}$ & NA \\
\hline & & & \multirow[b]{2}{*}[55]{} & \multirow{2}{*}{$\begin{array}{c}4 \text { years }(55) \\
5 \text { years }(191) \\
6 \text { years }(92) \\
\end{array}$} & \multirow{2}{*}{$\begin{array}{l}\text { Boys (175) } \\
\text { Girls (163) }\end{array}$} & \multirow{2}{*}{338} & Overt (.85) & Boys \\
\hline & & & & & & & Relational (.94) & none \\
\hline & & & {$[56]$} & 5 years $(313)$ & $\begin{array}{l}\text { Boys (163) } \\
\text { Girls (150) }\end{array}$ & 313 & Relational (.94) & NA \\
\hline & & & \multirow{2}{*}[57]{} & \multirow{2}{*}{6 years $(86)$} & \multirow{2}{*}{$\begin{array}{l}\text { Boys (46) } \\
\text { Girls (40) }\end{array}$} & \multirow{2}{*}{86} & Overt (.92) & None \\
\hline & & & & & & & Relational (.94) & None \\
\hline & & & \multirow{2}{*}[58]{} & \multirow{2}{*}{6 years $(126)$} & \multirow{2}{*}{$\begin{array}{l}\text { Boys (64) } \\
\text { Girls (62) }\end{array}$} & \multirow{2}{*}{126} & Overt (.86) & Boys \\
\hline & & & & & & & Relational (.89) & none \\
\hline \multirow{12}{*}{\multicolumn{2}{|c|}{$\begin{array}{c}\text { The Preschooler } \\
\text { Behavior } \\
\text { Questionnaire (PBQ) }\end{array}$}} & \multirow{12}{*}[34]{} & {$[59]$} & 5 years $(49)$ & $\begin{array}{l}\text { Boys (22) } \\
\text { Girls (27) }\end{array}$ & 49 & Hostile-Aggressive (.84) & NA \\
\hline & & & {$[60]$} & $\begin{array}{l}3 \text { years }(149) \\
4 \text { years }(68)\end{array}$ & $\begin{array}{l}\text { Boys (108) } \\
\text { Girls (109) }\end{array}$ & 217 & NA & None \\
\hline & & & {$[61]$} & 5 years $(325)$ & $\begin{array}{l}\text { Boys (169) } \\
\text { Girls (156) }\end{array}$ & 325 & Hostile-Aggressive (.78) & NA \\
\hline & & & {$[62]$} & $3-5$ years $(357)$ & $\begin{array}{l}\text { Boys (178) } \\
\text { Girls (179) }\end{array}$ & 357 & Hostile-Aggressive $\quad(.92)$ & NA \\
\hline & & & {$[63]$} & $\begin{array}{l}4 \text { years }(578) \\
5 \text { years }(401)\end{array}$ & $\begin{array}{l}\text { Boys (516) } \\
\text { Girls (463) }\end{array}$ & 979 & Hostile-Aggressive (.93) & NA \\
\hline & & & {$[19]$} & $\begin{array}{l}4 \text { years }(599) \\
5 \text { years }(403)\end{array}$ & $\begin{array}{l}\text { Boys (528) } \\
\text { Girls (474) }\end{array}$ & 1002 & Hostile-Aggressive (.94) & Boys \\
\hline & & & {$[20]$} & 5 years $(237)$ & $\begin{array}{l}\text { Boys (121) } \\
\text { Girls (116) }\end{array}$ & 237 & Hostile-Aggressive (.93) & Boys \\
\hline & & & {$[21]$} & $\begin{array}{c}3 \text { years }(38) \\
4 \text { years }(92) \\
5 \text { years }(107) \\
6 \text { years }(71) \\
\end{array}$ & $\begin{array}{l}\text { Boys (166) } \\
\text { Girls (142) }\end{array}$ & 308 & Hostile-Aggressive (.94) & Boys \\
\hline & & & {$[64]$} & $\begin{array}{l}3 \text { years }(42) \\
4 \text { years }(82) \\
5 \text { years }(97) \\
\end{array}$ & $\begin{array}{l}\text { Boys (118) } \\
\text { Girls (103) }\end{array}$ & 221 & Hostile-Aggressive (.96) & Boys \\
\hline & & & {$[65]$} & $\begin{array}{l}3 \text { years }(38) \\
4 \text { years }(60) \\
5 \text { years }(52)\end{array}$ & $\begin{array}{l}\text { Boys (88) } \\
\text { Girls (62) }\end{array}$ & 150 & Hostile-Aggressive (.92) & NA \\
\hline & & & {$[66]$} & $\begin{array}{c}3 \text { years }(98) \\
4 \text { years }(102) \\
5 \text { years }(119)\end{array}$ & $\begin{array}{l}\text { Boys (167) } \\
\text { Girls (152) }\end{array}$ & 319 & Hostile-Aggressive (.89) & NA \\
\hline & & & {$[67]$} & 5 years $(177)$ & $\begin{array}{l}\text { Boys (72) } \\
\text { Girls (105) }\end{array}$ & 177 & Hostile-Aggressive (.91) & NA \\
\hline \multirow{7}{*}{$\begin{array}{l}\text { Child } \\
\text { Behavior } \\
\text { Checklist } \\
\text { (CBCL): }\end{array}$} & \multirow{4}{*}{$\begin{array}{c}\text { for Ages } \\
1.5-5 \\
\text { years } \\
(\mathrm{CBCL} \\
1.5-5)\end{array}$} & \multirow{4}{*}[35,36]{} & {$[68]$} & 5 years $(299)$ & $\begin{array}{l}\text { Boys (153) } \\
\text { Girls (146) }\end{array}$ & 299 & $\begin{array}{c}\text { Externalizing behavior } \\
\text { problem }(.90)\end{array}$ & NA \\
\hline & & & {$[69]$} & $3-5$ years $(290)$ & NA & 290 & $\begin{array}{c}\text { Aggressive behavior } \\
(.87)\end{array}$ & NA \\
\hline & & & {$[70]$} & $\begin{array}{l}3 \text { years }(113) \\
4 \text { years }(118) \\
5 \text { years }(108)\end{array}$ & $\begin{array}{l}\text { Boys (191) } \\
\text { Girls (148) }\end{array}$ & 339 & $\begin{array}{l}\text { Externalizing behavior } \\
\text { problem }(.89)\end{array}$ & Boys \\
\hline & & & {$[71]$} & $\begin{array}{l}3 \text { years }(81) \\
4 \text { years }(90) \\
5 \text { years }(90)\end{array}$ & $\begin{array}{l}\text { Boys (132) } \\
\text { Girls (129) }\end{array}$ & 261 & $\begin{array}{l}\text { Externalizing behavior } \\
\text { problem }(.89)\end{array}$ & None \\
\hline & \multirow{3}{*}{$\begin{array}{c}\text { for Ages } \\
4-18 \\
\text { years } \\
(\mathrm{CBCL} \\
4-18)\end{array}$} & \multirow{3}{*}[15,37]{} & {$[72]$} & 5 years $(150)$ & NA & 150 & $\begin{array}{c}\text { Aggressive behavior } \\
(.87)\end{array}$ & NA \\
\hline & & & {$[73]$} & $\begin{array}{c}4 \text { years }(88) \\
5 \text { years }(147)\end{array}$ & $\begin{array}{l}\text { Boys (137) } \\
\text { Girls (98) }\end{array}$ & 235 & $\begin{array}{c}\text { Aggressive behavior } \\
(.78)\end{array}$ & NA \\
\hline & & & {$[74]$} & $\begin{array}{c}4 \text { years }(81) \\
5 \text { years }(216)\end{array}$ & $\begin{array}{l}\text { Boys (166) } \\
\text { Girls (131) }\end{array}$ & 297 & $\begin{array}{c}\text { Externalizing behavior } \\
\text { problem }(.85)\end{array}$ & NA \\
\hline \multirow{4}{*}{\multicolumn{2}{|c|}{$\begin{array}{l}\text { Social Competence } \\
\text { and Behavior } \\
\text { Evaluation } \\
\text { : the short form } \\
\text { (SCBE-30) }\end{array}$}} & \multirow{4}{*}[38,39]{} & {$[75]$} & $\begin{array}{c}4 \text { years }(81) \\
5 \text { years }(216)\end{array}$ & $\begin{array}{l}\text { Boys (166) } \\
\text { Girls (131) }\end{array}$ & 297 & Anger-Aggression (.83) & NA \\
\hline & & & {$[76]$} & $4-5$ years $(264)$ & $\begin{array}{l}\text { Boys (128) } \\
\text { Girls (136) }\end{array}$ & 264 & Anger-Aggression (.91) & NA \\
\hline & & & {$[77]$} & $\begin{array}{l}3 \text { years }(41) \\
4 \text { years }(60) \\
5 \text { years }(45) \\
\end{array}$ & $\begin{array}{l}\text { Boys (82) } \\
\text { Girls (64) }\end{array}$ & 146 & Anger-Aggression (.90) & NA \\
\hline & & & {$[78]$} & $\begin{array}{c}4 \text { years }(81) \\
5 \text { years }(216)\end{array}$ & $\begin{array}{l}\text { Boys (166) } \\
\text { Girls (131) }\end{array}$ & 297 & Anger-Aggression $\quad(.83)$ & None \\
\hline
\end{tabular}




\begin{tabular}{|c|c|c|c|c|c|c|c|}
\hline & & [79] & $\begin{array}{l}4 \text { years }(166) \\
5 \text { years }(342)\end{array}$ & $\begin{array}{l}\text { Boys (276) } \\
\text { Girls (232) } \\
\end{array}$ & 508 & $\begin{array}{c}\text { Relational }(.93) \\
\text { Overt }(.89)\end{array}$ & NA \\
\hline \multirow{3}{*}{$\begin{array}{l}\text { Child Behavior Scale } \\
\text { (CBS) }\end{array}$} & \multirow{3}{*}{ [40] } & [80] & $3-5$ years $(60)$ & NA & 91 & Total of child behaviors $(.87)$ & NA \\
\hline & & [81] & $\begin{array}{l}3 \text { years }(33) \\
4 \text { years }(56) \\
5 \text { years }(30)\end{array}$ & $\begin{array}{l}\text { Boys (67) } \\
\text { Girls (63) }\end{array}$ & 130 & Aggression (.89) & NA \\
\hline & & [82] & 4 years $(108)$ & $\begin{array}{l}\text { Boys (54) } \\
\text { Girls (54) }\end{array}$ & 108 & Aggression (.86) & NA \\
\hline $\begin{array}{c}\text { Social Behavior } \\
\text { Rating Scale (SBRS) }\end{array}$ & [11] & {$[83]$} & $3-6$ years $(110)$ & $\begin{array}{l}\text { Boys (55) } \\
\text { Girls (55) }\end{array}$ & 110 & Aggression (.90) & None \\
\hline
\end{tabular}

Note 1: NA = not available(could not be computed from information in original article, and author did not respond to request for information or could not supply it); None $=$ not significant.

Note 2: We converted Korean age of participants to western age in each of articles.

Table 2. Statistics for the meta-analysis of each measure

\begin{tabular}{|c|c|c|c|c|c|c|c|c|}
\hline Criterion & $K$ & $\mathrm{n}$ of Boys & $\mathrm{n}$ of Girls & Effect Size $(d)$ & $\mathrm{U}_{3}(\%)$ & $95 \%$ C.I. & Heterogeneity Q & $\mathrm{I}^{2}$ \\
\hline Total & 18 & 2457 & 2214 & 0.389 & 65.1 & 0.251 to 0.527 & $180.941^{* * *}$ & 85.631 \\
\hline Types of aggression & & & & & & & & \\
\hline Overt & 18 & 2457 & 2214 & 0.536 & 70.4 & 0.424 to 0.647 & $48.948^{* * *}$ & 65.269 \\
\hline Relational & 9 & 1026 & 879 & 0.102 & 54.1 & -0.148 to 0.351 & $59.138^{* * *}$ & 86.472 \\
\hline $\begin{array}{c}\text { The measure of } \\
\text { overt aggression }\end{array}$ & & & & & & & & \\
\hline PSBS & 10 & 1077 & 990 & 0.650 & 74.2 & 0.496 to 0.804 & $25.058^{* *}$ & 64.084 \\
\hline PBQ & 4 & 920 & 828 & 0.487 & 68.7 & 0.301 to 0.673 & $8.972 *$ & 66.561 \\
\hline CBCL & 2 & 323 & 277 & 0.105 & 54.2 & -0.178 to 0.387 & 0.001 & 0.000 \\
\hline
\end{tabular}

Notes: $k=$ the number of articles; $\quad$ Effect size $=$ Small (.2), Medium (.5), Large (.8); U3=Percentiles of nonoverlap ${ }^{*} \mathrm{p}<.05, * * \mathrm{p}<.01, * * * \mathrm{p}<.001$

First, thirteen out of 18 articles using the PSBS, the PBQ, and the CBCL showed that boys scored significantly higher than girls did in overt aggression, regardless of types of measures. In studies with the SCBE and the SBRS, boys and girls did not differ in overt aggression. Then, about relational aggression, boys were also more involved in aggressive behaviors than girls were in three articles using PSBS.

Results of meta-analysis on gender difference are presented in Table 2. Sample size of the studies used in meta-analysis was 4671 in total; 2457 boys $(52.6 \%)$ and 2214 girls $(47.4 \%)$. In a random effect meta-analysis model $(\mathrm{Q}=180.941, \mathrm{p}<.001 ; \mathrm{I} 2=85.631)$, the effect size of gender differences for the total of aggressive behaviors was .389 (C.I. $=.251$ to .527 ). The U3 value of the boy group was $65.1 \%$, which means the effect size of the aggression of boys is $15.1 \%$ higher than that of girls.

The variation of effect size was heterogeneous in overt aggression $(\mathrm{Q}=48.948, \mathrm{p}<.001)$, but not in relational aggression $(\mathrm{Q}=59.138, \mathrm{p}=.424)$. Mean effect size of gender difference was .536 in overt aggression and .102 in relational aggression. Although boys' scores were higher than girls' in both types of aggression, the gender difference was significant only in overt aggression (C.I. $=.424$ to .647 ). Gender difference in relational aggression did not reach the significance since the $95 \%$ confidence interval included 0 (C.I. $=-.148$ to .351$)$. The U3 value $(70.4 \%)$ in overt aggression indicated that the effect size of the aggression in boys was $20.4 \%$ higher than that in girls.
The effect size of the gender differences in overt aggression was .650 in the PSBS and .487 in the PBQ. The U3 values in the PSBS and the PBQ suggested that boys were more overtly aggressive than girls, while the mean effect size (.105) of the CBCL was not statistically significant.

\section{Discussion and Conclusion}

This study provided a review of measures of aggressive behaviors, which were used in 46 articles published in Korea over the past ten years. The Korean version of the measures was examined in terms of validity and reliability. This was followed by an examination of differing impacts of gender on aggression for each measure. The results are summarized and discussed as follows:

First, the most frequently applied measures of overt aggression in Korea were the PSBS, followed by the PBQ, the CBCL, the SCBE and the CBS. Only the PSBS assessed relational aggression. While the $\mathrm{CBCL}$ was a measure standardized for the Korean population, the rest of the measures were developed by overseas sources. These measures pertain to behavior rating and no observational method has been applied. Only the CBCL was rated by parents, while all other measures were rated by teachers

This implies that research findings on aggressive behaviors in Korea reflect perceptions, opinions, and beliefs 
of teachers rather than those of parents. Considering that aggressive behaviors often occur in social interactions [8], it may be difficult for parents to observe children's aggressive behaviors against peers. For this reason, teacher's rating could be an appropriate way to identify both relational and overt types of aggression. However, teacher-child ratios in most of the preschools and kindergartens in Korea were 1:15 30 for classes of children aged 4-5 [84]. Under this circumstance, the level of attention of teachers to detect aggressive behaviors of each child can be questioned. Thus, peer nomination shall be considered in parallel with the teacher's ratings especially for assessing relational aggression.

Secondly, Cronbach's alpha ranged between .70 and .97 for the most used three measures, indicating acceptable levels of internal consistency. This means that the Korean versions of the aggressive behavior measures are quite reliable. However, only a few articles provided the information on the validation.

When a researcher tries to use a measure developed by an overseas source, it is important to revise the original language version due to cultural and language differences [85]. Interpretation of aggressive behaviors is culturally diverse. An aggressive behavior conceptualized in the Western culture may have a different meaning in other cultures [86]. For example, children's taking out of turn in communication can be considered more impolite in the Asian Confusion culture. As a result, such a behavior will be discarded both by other children and adults. Therefore, it is important to develop a valid measure of aggression that reflects the characteristics of Korean culture. Furthermore, cultural equivalence between different language versions of a measure needs to be guaranteed in cross-cultural studies.

Finally, the result of the meta-analysis showed that gender difference depended on the types of aggression. It is found out that boys display significantly higher aggression. This was consistent in the PSBS, the PBQ and the CBCL and confirmed through the findings of previous studies [24, 28], stating that boys showed more physical aggression than did girls. Three articles using the PSBS reported that there were insignificant gender difference in relational aggression, meaning that gender differences in aggression were not significantly related to types of tool.

Previous studies maintained that the female disposition prioritizing relationships with others were associated with relational aggression. However, there has not been clear conclusion as to the question whether preschool girls display more relational aggression. This may be because gender differences in the orientation of social relationships have not been established for young children. A study [9] suggested that female relational aggression would be clearly identified only around school ages and adolescence when children's social cognition develops rapidly. This implies that gender differences in relational aggression may differ by developmental age.

The results of this study provide information how the tools measuring children's aggression are used in other cultures and how reliable and valid they are. Especially, it will provide preliminary information to researchers aiming to conduct a comparative cultural study involving Korea. In the future, relational aggression will need to be measured from multiple angles with the application of peer nomination and observation in addition to teachers' rating. Also, the age difference, which was not considered in this study, will help to explain gender differences in aggression.

\section{REFERENCES}

[1] Dodge KA, Crick NR. Social information-processing bases of aggressive behavior in children. Personality and Social Psychology Bulletin. 1990;16(1):8-22.

[2] Ostrov JM, Woods KE, Jansen EA, Casas JF, Crick NR. An observational study of delivered and received aggression, gender, and social-psychological adjustment in preschool:“This white crayon doesn't work...". Early Childhood Research Quarterly. 2004;19(2):355-371.

[3] Crick NR, Ostrov JM, Burr JE, Cullerton-Sen C, Jansen-Yeh E, Ralston P. A longitudinal study of relational and physical aggression in preschool. Journal of Applied Developmental Psychology. 2006;27(3):254-268.

[4] Johnson C, Ironsmith M, Snow CW, Poteat GM. Peer acceptance and social adjustment in preschool and kindergarten. Early Childhood Education Journal. 2000;27(4):207-212.

[5] Crick NR. Engagement in gender normative versus nonnormative forms of aggression: Links to socialpsychological adjustment. Developmental Psychology. 1997;33(4): 610-617.

[6] Bussey K, Bandura A. Social cognitive theory of gender development and differentiation. Psychological Review. 1999;106(4): 676-713.

[7] Yudofsky SC, Silver JM, Jackson W, Endicott J, Williams D. (1986). The Overt Aggression Scale for the objective rating of verbal and physical aggression. The American Journal of Psychiatry. 1986 Jan;143(1):35-39.

[8] Xie H, Swift DJ, Cairns BD, Cairns RB. Aggressive behaviors in social interaction and developmental adaptation: A narrative analysis of interpersonal conflicts during early adolescence. Social Development. 2002;11(2): 205-224.

[9] French DC, Jansen EA, Pidada S. United States and Indonesian children's and adolescents' reports of relational aggression by disliked peers. Child Development. 2002;73(4):1143-1150.

[10] Wakschlag LS, Briggs-Gowan MJ, Hill C, Danis B, Leventhal BL, Keenan K, et al. Observational assessment of preschool disruptive behavior, part II: validity of the Disruptive Behavior Diagnostic Observation Schedule (DB-DOS). Journal of the American Academy of Child \& Adolescent Psychiatry. 2008;47(6): 632-641.

[11] Schwartz D, Chang L, Farver JM. Correlates of victimization in Chinese children's peer groups. Developmental Psychology. 2001;37(4):520. 
[12] Cha ES, Kim KH, Erlen JA. Translation of scales in cross cultural research: issues and techniques. Journal of Advanced Nursing. 2007; 58(4):386-395.

[13] Schuster C, Hahn S, Ettlin T. Objectively-assessed outcome measures: a translation and cross-cultural adaptation procedure applied to the Chedoke McMaster Arm and Hand Activity Inventory (CAHAI). BMC Medical Research Methodology. 2010;10(1):106-114.

[14] Crijnen AAM, Achenbach TM, Verhulst FC. Comparisons of problems reported by parents of children in 12 cultures: total problems, externalizing, and internalizing. Journal of the American Academy of Child and Adolescent Psychiatry. 1997;36(9):1269-1277.

[15] Achenbach TM, Edelbrock C. Manual for the child behavior checklist and revised child behavior profile. Burlington (VT): University of Vermont; 1983.

[16] Achenbach TM, Dumenci L, Rescorla LA. Ratings of Relations Between DSM-IV Diagnostic Categories and Items of the CBCL/1 $1 \frac{1}{2}-5$ and C-TRF. Burlington (VT): University of Vermont, Research Center for Children, Youth and Families; 2000 .

[17] Oh KJ, Lee HR, Hong KE, Ha EH. The Korean version of Child Behavior Checklist. Seoul: Jungangjeokseong publisher;1997.

[18] Youngstrom E, Loeber R, Stouthamer-Loeber M. Patterns and correlates of agreement between parent, teacher, and male adolescent ratings of externalizing and internalizing problems. Journal of Consulting and Clinical Psychology. 2000;68(6): 1038.

[19] Lee YB, Lee YS. The influence of an infant's resilience on problem behaviors. Journal of Emotional and Behavioral Disorders. 2012;28(3):437-465.

[20] Kim K. Young children's social competence with attention ability, behavioral problems and emotional competence. Journal of Far East Social Welfare. 2009;5:81-102.

[21] Moon ES, Kim MH. The relationship between mothers' attitudes toward their children's expressiveness, teacher-child relationship and problematic behavior in preschoolers. The Journal of Eco-Early Childhood Education. 2011;10(2):59-81.

[22] Crick NR, Grotpeter JK. Relational aggression, gender, and social - psychological adjustment. Child Development. 1995;66(3):710-722.

[23] Asher SR, Singleton LC, Tinsley BR, Hymel S. A reliable sociometric measure for preschool children. Developmental Psychology. 1979;15(4): 443-444.

[24] Crick NR, Casas JF, Mosher M. Relational and overt aggression in preschool. Developmental Psychology. 1997;33(4):579-588

[25] Yoon JS, Barton E, Taiariol J. Relational aggression in middle school educational implications of developmental research. The Journal of Early Adolescence. 2004;24(3): 303-318.

[26] Moretti MM, Holland R, McKay S. Self-other representations and relational and overt aggression in adolescent girls and boys. Behavioral Sciences and the Law. 2001;19(1): 109-126.
[27] Smith CL, Calkins SD, Keane SP. The relation of maternal behavior and attachment security to toddlers' emotions and emotion regulation. Research in Human Development. 2006;3(1): 21-31.

[28] Ostrov JM, Keating CF. Gender differences in preschool aggression during free play and structured interactions: an observational study. Social Development. 2004;13(2): 255-277.

[29] Burton LA, Hafetz J, Henninger D. Gender differences in relational and physical aggression. Social Behavior and Personality: an International Journal. 2007;35(1): 41-50.

[30] Cohen J. Statistical power analysis for the behavioral sciences. Hillsdale (NJ): Lawrence Erlbaum Associates; 1988.

[31] Ioannidis JP, Patsopoulos NA, Evangelou E. Uncertainty in heterogeneity estimates in meta-analyses. British Medical Journal. 2007;335(7626):914-916.

[32] Crick NR, Bigbee MA, Howes C. Gender differences in children's normative beliefs about aggression: how do I hurt thee? Let me count the ways. Child Development. 1996;67(3):1003-1014.

[33] Crick NR, Werner NE. Response decision processes in relational and overt aggression. Child Development. 1998;69(6):1630-1639.

[34] Behar L, Stringfield S. A behavior rating scale for the preschool child. Developmental Psychology. 1974;10(5):601-610.

[35] Achenbach TM, Edelbrock C, Howell CT. Empirically based assessment of the behavioral/emotional problems of 2-and 3-year-old children. Journal of Abnormal Child Psychology. 1987;15(4):629-650.

[36] Achenbach TM, Rescorla LA. Manual for the ASEBA preschool forms \& profiles: an integrated system of multi-informant assessment. Burlington (VT): University of Vermont; 2000.

[37] Achenbach TM. Child behavior checklist/4-18. Burlington (VT): University of Vermont; 1991.

[38] LaFreniere PJ, Dumas JE. Social Competence and Behavior Evaluation: preschool edition (SCBE). Los Angeles (CA): Western Psychological Services; 1995.

[39] LaFreniere PJ, Dumas JE. Social competence and behavior evaluation in children ages 3 to 6 years: the short form (SCBE-30). Psychological Assessment. 1996;8(4):369-377.

[40] Ladd GW, Profilet SM. The child behavior scale: a teacher-report measure of young children's aggressive, withdrawn, and prosocial behaviors. Developmental Psychology. 1996;32(6):1008-1024.

[41] Doh H, Shin N, Kim MJ, Park B, Na J. The mediating effect of maternal abuse and neglect on the relationship between socioeconomic status and preschoolers' social behavior. Journal of Korean Home Management Association. 2012;30(5):107-119.

[42] Kwon YH. The relationships between maternal parenting behaviors and children's aggressions: The moderating role of teacher-child conflictual relationship. The Journal of Korea Open Association for Early Childhood Education. 2012;17(1):1-19. 
[43] Choi IS, Lee K. The effects of social information processing and emotional factors on preschoolers' overt and relational aggression. The Korean Journal of Child Studies. 2010;31(6):15-34.

[44] Min SH. The effects of maternal responses, Preschoolers' narrative representations, inhibition, and emotional regulation on preschoolers' physical and relational aggression. The Korean Journal of the Human Development. 2009;16(1):21-40.

[45] Lee KN. The effects of individual characteristics and teacher-child conflictual relationships on young children's aggression. Family and Environment Research. 2014;52(3):229-241.

[46] Jeong M, Lee $\mathrm{H}$. The mediating effects of parental rejective parenting and teacher-child conflictual relation on young children's aggression and adjustment to early childhood education institution. The Korean Journal of Child Education. 2014;23(4):377-390.

[47] Yoon SJ, Kim MK. Teacher-Child relationships and peer relationships by young children's aggression. Journal of Korean Child Care and Education. 2011;7(4):49-68.

[48] Kwon YH. Children's relational and overt aggression in relation to their negative emotionality, emotional regulation, and maternal parenting behaviors. Korean Journal of Human Ecology. 2011;20(5):927-940.

[49] Choi IS. The effects of preschool children's language ability, emotion regulation, and mothers' parenting behavior on peer competence and aggressive behavior. Journal of Korean Home Management Association. 2014;32(6):47-58.

[50] Han JA, Cho Y, Kim J. Effects of preschool children's gender, temperament, emotional regulation and maternal parenting stress on children's overt aggression and relational aggression. Korean Journal of Human Ecology. 2014;23(4):599-611.

[51] Kim J, Chung JN, Kwon YH, \& Min S. Relations between mothers' responses about their preschoolers' overt and relational aggression by preschoolers' aggressive behaviors. The Korean Journal of Child Studies. 2009;30(2):145-159.

[52] Cho CY, Kwon YH. The role of child's emotional intelligence and verbal ability on the relations between mother's rejective parenting and child aggression. Korean Journal of Child Education and Care. 2014;14(1):51-72.

[53] Lee SB, Shin Y. Associations of aggression, maternal rejection/neglect, child temperament, and daycare experience: The moderating effect of self-regulation. Journal of Korean Home Management Association. 2010;28(3):73-80.

[54] Shin YL. The influence of maternal love withdrawal, preschoolers' emotional regulation, verbal ability on relational aggression. Journal of the Korean Home Economics Association. 2010;48(7):15-22.

[55] Lee SB, Shin Y. Effects of child, day care, and home variables on physical and relational aggression of preschool children. Journal of the Korean Home Economics Association. 2011;49(9):111-120.

[56] Shin YL. Trajectories of relational aggression in preschool children by the latent growth curve model. Journal of the Korean Home Management Association. 2012;30(2):189-196.

[57] Park S, Song H. The influence of mothers' emotion expressiveness and children's attributional biases on children's aggressive behavior: gender differences between boys and girls. Journal of Korean Child Care and Education. 2014;10(4):27-42.

[58] Lee J. The relations among young children's emotion regulation, social information processing and aggression depending on sex. The Journal of Child Education. 2011;20(3):225-241.

[59] Kwon MN, Ohm JA. The relationships between the entry behaviors into a play group in indoor ' outdoor free-play time and social behaviors of preschoolers. Journal of Educational Studies. 2011;42(2):137-156.

[60] Hong HJ, Moon HJ. The effect of children's temperament, mother's parenting behavior, and teacher-child relationships on children's behavior problems. The Journal of Eco-Early Childhood Education. 2013;12(4):245-274.

[61] Han N, Moon H. The effect of children's behavior problem, father's child rearing involvement, and home environment on children's learning behavior. Early Childhood Education and Care. 2014;9(3):25-49.

[62] Oh J, Shim S. Children's social-emotional behavior problems and maternal related variables by mediating parenting efficacy. Journal of Korean Council for Children and Rights. 2013;17(1):79-108.

[63] Lee YS. Problematic behavior according to the children's resilience type. Journal of Early Childhood Education and Educare Welfare. 2014;18(4):61-91.

[64] Choi S, Hwang H. Relationship of the quality of teacher-preschooler interaction to the maladjusted behaviors of preschoolers. Korean Journal of Children's Media. 2011;10(3):1-18.

[65] Kim S. The effect of mother's acculturation on young children's behavior problems in multi-cultural family: parenting as mediator. Journal of Early Childhood Education. 2010;30(6):95-115.

[66] Lee HS, Kang MW. The job satisfaction of working mothers, their children's emotional expression and the children's behavior problems. Korean Journal of Child Education and Care. 2010;10(4):73-86.

[67] Park JY, Kang S, Kwon KS. The relations among children's temperament and peer competence, maternal child-rearing attitudes, and the children's behavioral problems. Journal of Future Early Childhood Education. 2010;17(4):139-162.

[68] Yim M, Moon H. Parental conflict, parental intelligence on preschooler's internalizing problems and externalizing problems. The Korean Journal of the Human Development. 2014;21(1):159-179.

[69] Hyun E, Park EM, Cho MM, Kim TY. Relationship among mothers' smartphone addiction levels, maternal depression and young children's problem behaviors. Korean Journal of Early Childhood Education. 2013;33(5):181-205.

[70] Kang JH, Oh KJ. Gender differences in the effects of preschoolers' age, temperament and parenting for internalizing and externalizing problems. The Korean Journal of Woman Psychology. 2011;16(1):1-21.

[71] Kim M, Kang J. The mediating effects of maternal attitudes toward preschoolers' expressiveness on the relation between mother's ambivalence over emotional expressiveness and 
preschoolers' problem behaviors. Korean Journal of Counseling. 2012;13(6):2803-2820.

[72] Lee CS, Lee CH. A structural sample of the effects of parent's rating attitude, temperament, social competence on young children's problem behavior. Early Childhood Education Research and Review. 2009;13(5):27-44.

[73] Min HY, Lee YM. The effect of mothers' collective parenting values on preschoolers' aggressive and anxious behaviors: Marital satisfaction as a mediating variable. Family and Culture. 2009;21(4):21-39.

[74] Shin YL. The effects of self-concept, hyperactivity, and behavioral problems on peer harassment in preschool children. Journal of the Korean Home Economics Association. 2008;46(7):85-93.

[75] Shin YL. Effects of individual and classroom contexts on peer victimization of preschool children. Journal of Korean Home Management Association. 2009;27(6):13-20.

[76] Kim JH, Shin YL. Moderating effects of mother- and teacher-child intimacy on the relationship between the child's social behaviors and peer rejection. Journal of Life-Span Studies. 2011;1(2):17-29.

[77] Choi Y. A study on the relationship of children's playfulness and emotion regulation to social competence. Early Childhood Education and Care. 2011;6(2):147-164.

[78] Shin YL. Social Behaviors, psychosocial adjustments, and language ability of aggressive victims, passive victims, and bullies in preschool children. Journal of the Korean Home
Economics Association. 2011;49(6):1-12.

[79] Yoon SJ, Shin YL. The mediating and moderating effects of teacher-child relationships on social behavior and peer preference. Journal of the Korean Home Economics Association. 2012;50(5):67-77.

[80] Kim EK, Ohm JA. The relationships among child's social play behaviors with a sibling, the sibling's birth order and gender, the child's temperament, and peer competence. Journal of Early Childhood Education. 2013;33(5):161-179.

[81] Kim M, Kim J. The correlation between the mothers' happiness and preschoolers' attachment stability, and peer competence. Journal of Early Childhood Education and Educare Administration. 2010; 14(2):5-28.

[82] Lee S, Ha MS. The influence of children's emotional intelligence on theory of mind and peer competence. The Journal of Eco-Early Childhood Education. 2009;8(4):211-233.

[83] Kwon YI. Early childhood education in Korea: Discrepancy between national kindergarten curriculum and practices. Educational Review. 2004;56(3): 297-312.

[84] Sidani S, Guruge S, Miranda J, Ford - Gilboe M, Varcoe C. Cultural adaptation and translation of measures: an integrated method. Research in Nursing \& Health. 2010;33(2): 133-143.

[85] LaFreniere P, Masataka N, Butovskaya M, Chen Q, Dessen MA, Atwanger, K., et al. Cross-cultural analysis of social competence and behavior problems in preschoolers. Early Education and Development. 2002;13(2):201-220. 